\title{
Diagnosing the Problems in Teaching Courses of English for Specific Purposes at the University of Prishtina and Private Colleges in Kosovo
}

\author{
Shqipe Husaj \\ Prof. Ass. Dr. , University " Fehmi Agani " Gjakove, Kosovo
}

\begin{abstract}
A number of academic units at the University of Prishtina (UP) offer English for specific purposes in order to address the needs of students to communicate effectively in their chosen field of study. Recent developments and the changing landscape of teaching and learning English for Specific Purposes around the world lead to the decision of analyzing a complex of factors that affect or hinder the effectiveness of the process of teaching and learning ESP courses at the University of Prishtina as well as at the private colleges in Kosovo. The research questions include: What are the problems faced by students learning ESP at the University of Prishtina and at the private colleges in Kosovo? What are the ways of solving these problems? etc. The data has been collected by conducting a survey in six academic units of the University of Prishtina including both teaching staff and student population. The selection of academic units is done on the bases of their specificity of the study field. That means the faculties that need a more specific vocabulary of English Language. There has also been conducted a survey in three private colleges considered as more successful colleges; "Dukagjini" College, AAB College and the College "Biznesi". Theoretical part is based on outstanding scholars and researchers of the English for Specific Purposes . Research findings have confirmed our research hypothesis displaying expected pattern of obstacles faced by the teaching staff and students in the process of teaching and learning ESP courses. Status of the course, large number of students in groups, lack of equipped laboratories and lack of qualified staff, present a hindrance in achieving the objectives of ESP courses at the University of Prishtina. While in private colleges it is students' low knowledge of English language that prevents the teaching of English for Specific Purposes thus concentrating more on General English (GE).
\end{abstract}

Keywords: specific purpose, students, colleges, language, knowledge, etc.

\section{Introduction}

\subsection{The University of Prishtina and English Language for Specific Purposes}

The UP was founded in November 1969 as the first university in Kosovo and as the legal entity aiming to offer academic services, research, professional consulting and artistic work as well as other academic activities. At the beginning the UP started work with the following faculties: The Faculty of Philology, the Faculty of Law and Economy, the Faculty of Technology and the Faculty of the Medicine. Later on the UP continued to develop consisting of seventeen affiliates/ faculties in different towns of Kosovo such as Gjakovë, Pejë, Mitrovicë and Gjilan. The university units in these towns primarily functioned as colleges / university high schools to be transformed later on into faculties but, as sub- branches of faculties in Prishtina. For example the Economic High School in Peja was a sub-branch of the Faculty of Economics in Prishtina functioning with the same teaching programs and even with some of the same teaching staff. The same is with the Faculty of Education and Philology in Gjakova. Today not all the above mentioned faculties are part of UP because they got transformed into separate public universities. However, all Faculties of UP organize English courses, some of them General English and some of them English for Specific Purposes.

It is widely accepted that learning/teaching General English differs from the process of learning/teaching English for Specific Purposes (ESP), as it requires different vocabulary based on the study field that students are focused on. English for Specific Purposes (ESP) is a new and developing branch of EFL in Kosovo. With the spread of the student-centered approach and the continued increase of international contacts in various spheres, much attention has been paid to the design of ESP courses that can prepare students for professional communication. For many years ESP teachers and 
instructors have been trying to bring different teaching methods and textbooks in their class by designing a course that can best serve learners' interests and needs. Such attempts and methods do not reflect students' interests and result in low learner motivation and poor participation. Hence, this work is dedicated to researching the process of teaching and learning English language within the University of Prishtina and private colleges in Kosovo. The reason why it is decided for this issue is the problem whichstudents face during their studies in using professional literature in English language as well as after graduation feeling handicapped in their working place.

The University of Prishtina as mentioned above consists of sixteen academic units, all of a different study field. However, the research is conducted only in a number of the academic units, more precisely in six of them, which need to teach their students English language focusing on particular field and specific vocabulary since each study program requires a specific vocabulary that differs from that of everyday English. For instance, the vocabulary of justice is completely different from that of the philology or medicine, as is the vocabulary of engineering different from that of arts. This research aims to highlight these problems faced by teaching staff and students of the UP and private colleges operating in Kosovo and hopefully serve as an incentive for teachers towards designing ESP syllabuses and courses. However students learn what they are taught. ${ }^{1}$

\section{Literature Review}

In this chapter is considered the ESP and its meaning defined by the literature reviewed according to the research questions and study, its development and classification. ESP helps students master English language in their further studies and future career, what is the teachers and students commitment towards ESP, whether students want to learn general English combined with ESP and whether instructors feel competent enough to teach ESP courses.

The first part of this chapter contains the description of ESP and its origin. Theoretical part based on outstanding scholars of ESP, according to different scholars and researchers on the field of English language especially English for Specific Purposes. It also describes the difference between ESP and General English, effect of ESP on students' career and working place, objectives of ESP as well as quality assessment on ESP teaching. Attitude towards learning a language is vital to students success, therefore attitude must be taken into account when designing the course of ESP. Writers and researchers consulted and cited in this doctoral thesis are Tony, Dudley - Evans., Maggie Jo St John., Harding, Kelly., Holliday, Adrian., Hutchinson, Tom., Alan, Waters., Kristen., Gatehouse, Richard \& Theodore, Rodgers., Robinson, Pauline., Hinkel,E., Dickinson Emily.,Geffner, Andrea.B.Basturmen.,H. and many others (found on the list of references). There are some other academic papers and websites consulted and considered as supporting or secondary literature. It should be mentioned that the researcher faced difficulties with literature because all internet resources, even they are in a large number are not available for everyone. However, everything used is mentioned as reference or citation.

When teaching ESP there are certain basic questions to be taken into account such as: who the learners are, what their view towards language learning is, what particular skills they will be needing in their account, on the job situation, what their linguistic background or level of competence is, what their purpose and expectations are, and others . According to an article in the magazine English Teaching Professional,(Rosenberg 2004) has analyzed the differences between English for Specific Purposes and General English. In her article she considers where English for Specific Purposes, respectively Business English and General English meet. To deal with these questions more seriously and specifically, the author of the article has conducted a survey. She has asked a group of University teachers of the English language to find out the differences and the similarities between general English and Business English. ${ }^{2}$

\section{Research Methodology, techniques and instruments}

In order to elaborate the chosen topic for this $\mathrm{PhD}$ thesis, the following research methods and instruments were used:

\subsubsection{Research Methods}

- Descriptive method,

\footnotetext{
${ }^{1}$ This paper is a summer of the author's PhD thesis

2 This paper is a summer of the author's PhD thesis
} 


\section{- Qualitative method, \\ - Quantitative method and \\ - $\quad$ Comparative method}

\subsubsection{Instruments used}

\begin{tabular}{ll} 
- & Observations \\
- & Survey \\
- & Interviews / discussions \\
\hline
\end{tabular}

\subsection{Limitations}

The ongoing process of the research was not an easy one. Prior to conducting the research several steps had be taken: First of all, each academic units were visited and the Deans of respective academic units were contacted in order to inform them about the purpose of the research and provide their approval. Not all respondents were ready to agree on the questionnaire asking hundreds of answer by, how, when, why exactly me, etc. The researcher could not finish everything on the first visit even though there was a prior appointment set for a certain date, so I had to travel many times to the same unit. Some of the respondents wanted to see sample questionnaires filled in by the other colleagues and things like that. The same was with the students who expressed a kind of fear of having consequences if their teachers discover that they signed the questionnaire, it was needed an effort to convince them that no one knows who filled in the questionnaires. But everything is good when it ends well.

\subsection{Research population}

Selection of people to be included in the research needs a particular attention because on those people depends the validity, fairness and result of the research. As in this research are involved only six faculties of the UP and three private colleges then, research population sample includes the teaching staff and students of the selected academic units (twenty to thirty-fife students and the teaching staff at each unit of the UP and forty students and the teaching staff at each college). Questionnaires were distributed on site to the students while they were having lectures in whatever course ( with the previous permission of the course teacher) and interviewing them during the break time in the faculty failities, but with the teaching staff was a bit more difficult as not all of them felt ready to respond. Respondents included in the research are from those academic units which require more specific and different English vocabulary from the others such as the Faculty of Arts which has a completely different vocabulary from the Faculty of Economics, or the vocabulary of English language used in the Faculty of Law which has nothing in common with the vocabulary of the English language used in the Faculty of Medicine. So, responses generate from the site visits. In order to have better result both descriptive and interferial statistics are used in the research. ${ }^{1}$

\section{ESP Courses at the University of Prishtina - Data Analysis}

\subsection{Analysis of the Syllabi}

Like all universities around the world that are required to undergo the accreditation process with its primary purpose of quality assurance and development, the University of Prishtina as an institutions of higher education, is too. All higher Education Institutions are judged based on a self -evaluation report, analyzing how well they meet the standards required by both internal accreditation agency (KAA) and external or International accreditation by experts of certain countries in the field of education. The Universities in Kosovo as well, have to modify their teaching programs according to the recommendations given by the experts of International Accreditation Agency for their re-accreditation. The University of Prishtina, as the largest public university in Kosovo, consists of sixteen academic units with about 200 study programs in three levels of studies. At the beginning of the academic year each university unit prepares their syllabi according to the rules and requirements set by Accreditation Agency of Kosovo supervised by International Accreditation Agency. It is true

\footnotetext{
${ }^{1}$ This paper is a summer of the author's $\mathrm{PhD}$ thesis
} 
that one of the main focus of the agency among the others, is put on English language teaching with the particular attention on ESP because many grants are being offered to every unit for exchange students and other forms of finishing their studies at both European and American universities. Such grants are also applicable for university teachers, and very often there are difficulties finding students /teachers whose level of English is sufficient to be selected for those programs. So, wanted or not syllabi have to be composed according to the requirements but, the issue is whether in reality such syllabi are applied or not. In this thesis it is given an attempt to find out the causes and the consequences of the existing situation.

Teachers of ESP courses have often been criticized for lacking the specialty knowledge necessary for a complete understanding of target language materials. As a result, many ESP teachers feel insecure in the classroom, lack confidence about their abilities to teach the course, and become overly sensitive to the views of specialists regarding the course design, materials, and in-class activities. When designing the course there are several questions to be considered, such as;

-What are course materials - common core or specific to students' study field?

Common core materials- which are either of a general academic nature or of a general professional nature, focus more on reading skills, such as "establishing main point" or "inferring meaning from context' that form the major part of the EAP courses, and can validly be taught in an intermediate to Advanced General English course.(Picket,1989), while specific materials include career content/ real content materials which are essential to the understanding of ESP work and to an understanding of motivation in ESP, such as; topics in AEP students follow in their courses of EOP/EBP related students use.( Bates \& Dudley - Evans, 1976).

- Is the focus broad or narrow?

The specificity inESP should be clarified based on its content. Broad focus skills are dealt in details and teaching materials include specific carrier content. The notion "carrier content" and "real content" according to Bates and Dudley Evans (1976. p.12) are essential to the understanding of motivation in ESP. It means any activity no matter if it aim teaching language or skills must be presented in a context. While narrow focus

When the knowledge and needs of students are limited and concentrated on those needs. Bates and Dudley-Evans in a short extract from Nucleus (on p.12) give an example of carrier content and real content. If tables of statistics are used to teach the language of comparison then the statistics constitute the carrier content and the real content is the language used to make the comparison. ${ }^{1}$

-Should the course be designed by the teacher prior or after the consultation with the students and the institution?

This, because in some institutions, especially in private colleges the level of language knowledge is really low and teachers have to design the course according to that level otherwise it would be worthless out of it.

Another issue to consider when designing the course is teachers' knowledge of specific language vocabulary as the teacher is always considered as the provider of input in the class and is expected to be well prepared prior to the lectures start. This is why in some units of UP and especially in private colleges the ESP in not applicable. In this study, it has been argued that ESP teachers are quite similar to students in their desire to know more about the language of the target field, and their weaknesses when it comes to understanding the target material. By lowering their own status as all-knowing experts of the subject matter, and raising that of students as valuable contributors to classroom discourse, ESP teachers can create a more productive atmosphere that ultimately leads to greater all-round learning.

Analyzing the syllabuses of the courses offered at the academic units included in the research, several clashes are observed:

Not all the academic units have the same workload nor the same number of ECTS credits as the number of ECTS 25-30 credits depends on the number of classes held per week. Based on the regulation for academic development one ECTS credit requires 25 - 30 course classes depending on the students' commitment and the importance of the course meaning if the course is considered as main/ primary course for that study field or as secondary course. In the Faculty of Law and Economics, the course of Accounting and Finance Corporate are treated as the primary courses while other courses like the course of Business Fundamentals or Academic writing are treated as elective or compulsory courses. Furthermore, the

${ }^{1}$ This paper is a summer of the author's $\mathrm{PhD}$ thesis 
faculty of Agriculture, for instance, English for specific purposes is an obligatory course, taught six classes per week in the first and second year of studies in both semesters, and has 3 ECTS credits. But in the Faculty of Economics, even though it is an obligatory course, it is taught only one semester and bears 6 ECTS credits in the first and second year of studies. On the other hand, in the Faculty of Arts the English language course is an elective course, taught only one semester per year, taught two hours per week and has 7 ECTS credits and only two classes per week. In the Faculty of Applied Sciences the English course is an elective course in both first and second year of studies taught only one semester per year, four classes a week and has 6 ECTS credits. This shows that there is great diversity in the treatment of the same course and needs an immediate action in regulating the status and the importance of the English language courses at the University of Prishtina. There are rules set for ECTS calculation but it seems that not all teachers do proper calculation of ECTS credits. (See syllabi in the appendix A). The ECTS system is defined in the European Credit Transfer and Accumulation System (ECTS) framework by the European Commission. It is a standard for comparing the study attainment and performance of students of higher education across the European Union and other collaborating European countries (www.wikipedia, ECTS grading system). Even though 32 ministers responsible for vocational training in those 32 European countries agreed to develop in the Maastricht Communique of 14 December 2004, the calculation of credits is not fixed the same for all of them. It differs from country to country but, not from one institution to the other within the same country. One ECTS credit requires 25-30 teaching hours. It must be understood that ECTS is not just a figure showing the classes held with the students but, also student's individual work, the student's learning outcomes and much more, something really confusing for those who have to calculate them. So if the course has 6 ECTS credits there have to be 180 hours of student's commitment. There has been a general note given by the IAA on ECTS incorrect calculation about all universities, not only UP. Hope there has been an improvement since the research was done.

\subsubsection{The aim of the English for Specific Purposes course}

Based on the syllabuses collected and analyzed, the aim of the English courses (ESP) in each academic unit is to provide opportunities for students to gain knowledge and skills in order to understand, explain, and communicate in their study field, be able to read, translate from English into Albanian or Albanian into English, write reports about the research on the field, and of course write letters, correspondences, medical reports, business letters and have discussions in English. As it can be seen from the syllabuses every academic unit uses the adequate literature necessary for the particular study field as well as additional literature and exercises taken from different web pages in order to familiarize students as much as possible with professional vocabulary. In the faculty of Economics for instance, the textbooks used is English for Business Studies by lan Mac Kenzie; Cambridge University Press, (2007), and Exercises in Business

Correspondence by Ljerka Sedlan, Konig (2007), the faculty of Law - English for Lawyers by Alison Riley - Macmillan Publishers, (1991), Law today - I - by Richard Powe- Longman, (1993), or English in Medicine by Eric H. Glendinning (2005), in the faculty of Medicine,etc.

\subsubsection{Learning outcomes of the ESP course}

Judging from the course syllabi, by the end of these courses students of each academic unit will be able to deal with business, art, medicine, science, technology, legal issues and all other particular situations related to their study field and use specific vocabulary, write letters, compile essays on various professional subjects, carry on discussions and similar. Students will also be able to clearly conduct job interviews, organize a trade fair and conferences, identify the specific skills of workers and needs of specific jobs and vocations, practice the language of talking about job skills. Good teaching enhances many aspects of learning. However, effective personal learning also depends on learners' attitudes, values and responses. Students are teachers' partners in the educative process and are largely responsible for their own learning. Students who understand goals and key to meet standards are likely to have better learning outcomes.

Teaching methodology in all researched academic units involves using the best possible methods such as: pre-teaching of the vocabulary, discussion of the meaning of the new words, listening focused tasks, paraphrasing, correctness, "informational feedback" as a filter that helps increase motivation, increase accuracy and extend repertoire, grammar exercises, etc. all these conducted in small groups or individual discussions, seminars etc.

Note: Syllabuses collected from the academic units teaching ESP, together with samples of questionnaires used in research are given in the appendices.

\subsection{Analysis of the responses provided by teaching staff}


One of the most important factors in effective learning is monitoring students' progress. Professors not only need to recognize their shortcomings but also figure out their accomplishments. Recently there has been a new development highlighting the students' success experiences. The main success of students is bound to the enhanced motivation and confidence boost that is vital in the process of language learning by fostering professors' positive attitude. As the language consultant, the teacher attention must be focused on gathering materials familiar to the students study field, materials which have already been covered or will be covered in other subjects in Albanian language (for the students of Kosovo), as ESP is a kind of sub-study /or a second study of the same subjects but in another language. So, there is always a constant evaluation of course design, material modification, technology use and assessment tests as a priority of the teacher in order to achieve desired success and goals set forward at the beginning of the academic year in the course syllabus. The analysis of the data provided by the teaching staff will provide us an insight whether this success is a realistic goal to be accomplished by the teaching staff of the University of Prishtina in delivering ESP courses. The appendix A represents two complete questionnaires containing thirty questions each that helped us collect data relevant to the teaching process at the University of Prishtina compared to three private colleges in Kosovo.

\section{Findings and Interpretation of Data}

The University of Prishtina with its sixteen academic units face problems of different nature, amongst which is the process of ESP teaching and learning. Based on the research conducted in only six academic units of the University of Prishtina, there are some findings that present some problems that should be seriously taken into consideration and a lot of effort is required in order to find solution. English language nowadays is not considered a luxury of the day, but rather a necessity for every person regardless whether they are students or already employed, if they are young or old in age. No modern life can be run without English, especially English for Specific Purposes which provides students with the knowledge and communication skills in their study field.

\subsubsection{Testing of Research Hypothesis}

Based on the recent developments in the field of ESP, the ultimate aim of the research was to verify our main hypothesis listed below.

For this study is used this model

$Y=\beta 0+\beta 1 X 1+\beta 2 X 2+\beta 3 X 3+\beta 4 X 4+\varepsilon i$

$Y=$ (dependent variable) that expresses: Teaching ESP at the University of Prishtina and Private colleges in Kosovo.

$X_{1}=$ Lack of teaching staff

$\mathrm{X}_{2}=$ Computer training for teaching staff

$\mathrm{X}_{3}=$ Contemporary alternative teaching methods

$\mathrm{X}_{4}=$ Selection of authentic materials

The instrument used to verify our hypothysis is T-Test ${ }^{1}$

\section{T-TEST}

/TESTVAL $=0$

/MISSING=ANALYSIS

NARIABLES=Q1 Q2 Q3 Q4

ICRITERIA=Cl(.95).

\footnotetext{
${ }^{1}$ This paper is a summer of the author's PhD thesis
} 


\section{One-Sample Statistics}

\begin{tabular}{|l|l|l|l|l|}
\hline & N & Mean & Std. Deviation & Std. Error Mean \\
\hline Lack of teaching staff & 4 & 2.50 & 1.291 & .645 \\
Computer training for teaching staff & 5 & 3.00 & 1.581 & .707 \\
Contemporary alternative teaching & 5 & 2.80 & 1.304 & .583 \\
Selection of authentic materials & 3 & 2.00 & 1.000 & .577 \\
\hline
\end{tabular}

Tab.39. Test statistics

\section{One-Sample Test}

\begin{tabular}{|c|c|c|c|c|c|c|}
\hline & \multicolumn{6}{|c|}{ Test Value $=0$} \\
\hline & \multirow[t]{2}{*}{$\mid \mathrm{T}$} & \multirow[t]{2}{*}{ Df } & \multirow[t]{2}{*}{ Sig. (2-tailed) } & \multirow[t]{2}{*}{ Mean Difference } & \multicolumn{2}{|c|}{$\begin{array}{l}95 \% \text { Confidence Interval of } \\
\text { the Difference }\end{array}$} \\
\hline & & & & & Lower & Upper \\
\hline Lack of teaching staff & 3.873 & 3 & .030 & 2.500 & .45 & 4.55 \\
\hline $\begin{array}{l}\text { Computer training for } \\
\text { teaching staff }\end{array}$ & 4.243 & 4 & .013 & 3.000 & 1.04 & 4.96 \\
\hline $\begin{array}{l}\text { Contemporary alternative } \\
\text { teaching }\end{array}$ & 4.802 & 4 & .009 & 2.800 & 1.18 & 4.42 \\
\hline $\begin{array}{l}\text { Selection of authentic } \\
\text { materials }\end{array}$ & 3.464 & 2 & .074 & 2.000 & -.48 & 4.48 \\
\hline
\end{tabular}

Tab.40. test statistics

FREQUENCIES VARIABLES=Q1 Q2 Q3 Q4

IORDER=ANALYSIS.

\section{Statistics}

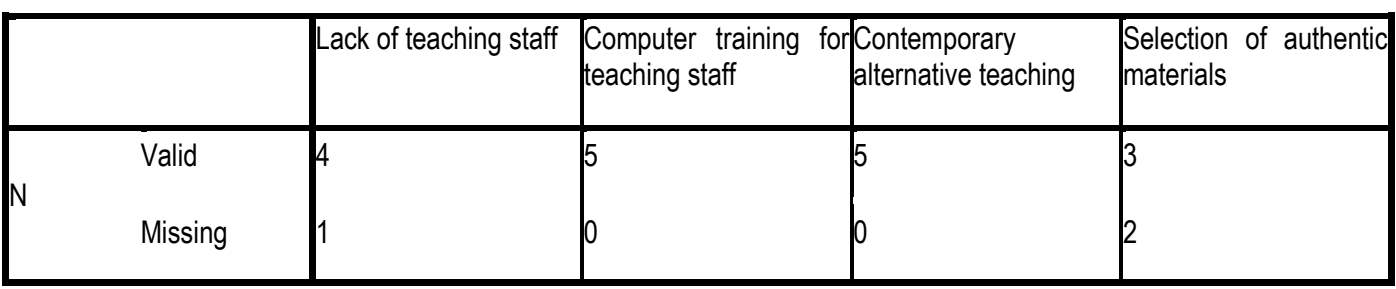

Tab.41. test statistics

$\rightarrow$ Hypothesis I:Diagnosing the problems in teaching/ learning ESP helps a lot the improvement of ESP acquisition. $(\mathrm{t}=3.873 \text {,Sig. }=.030)^{1}$

\footnotetext{
${ }^{1}$ This paper is a summer of the author's PhD thesis
} 


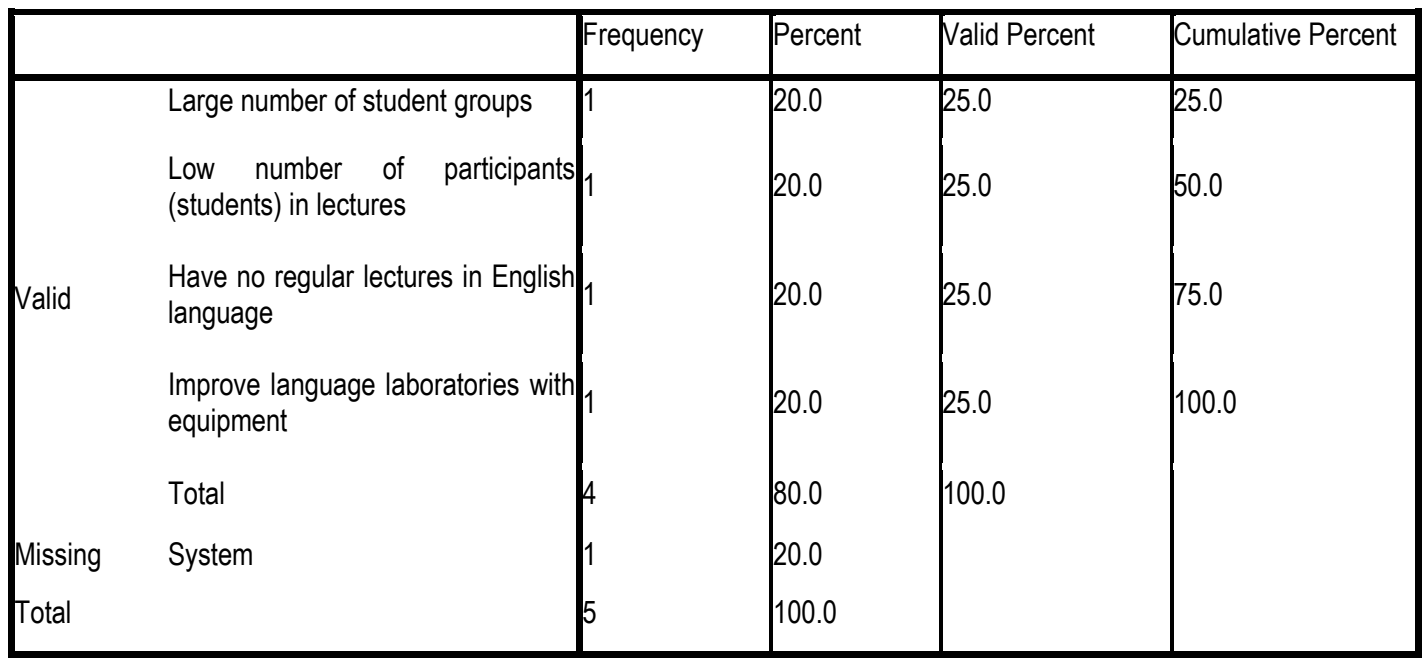

\section{Tab.42. test statistics hypothesis}

Based on the figures given by the Test the identification of the problems faced by both teachers and students during the teaching process is the most important thing and as a result the test proves the hypothesis as positive $(t=3.873$,Sig.= $.030)$.

\section{The use of Contemporary alternative teaching methods}

\begin{tabular}{|l|l|l|l|l|}
\hline & Frequency & Percent & Valid Percent & Cumulative Percent \\
\hline Group work & 1 & 20.0 & 20.0 & 20.0 \\
$\begin{array}{l}\text { Seminar presentations/computer and } \\
\text { projector }\end{array}$ & 1 & 20.0 & 20.0 & 40.0 \\
Audio-lingual & 1 & 20.0 & 20.0 & 60.0 \\
The text analysis technique & 1 & 20.0 & 20.0 & 80.0 \\
Techniques for building vocabulary & 1 & 20.0 & 20.0 & 100.0 \\
Total & 5 & 100.0 & 100.0 & \\
\hline
\end{tabular}

Tab.43. test statistics

Further training for teaching staff

\begin{tabular}{|c|c|c|c|c|c|}
\hline & Frequency & Percent & Valid Percent & Cumulative Percent \\
\hline \multirow{3}{*}{ Valid } & 25 & 1 & 20.0 & 20.0 & 20.0 \\
\hline & 10 & 1 & 20.0 & 20.0 & 40.0 \\
\hline & 35 & 1 & 20.0 & 20.0 & 60.0 \\
\hline
\end{tabular}




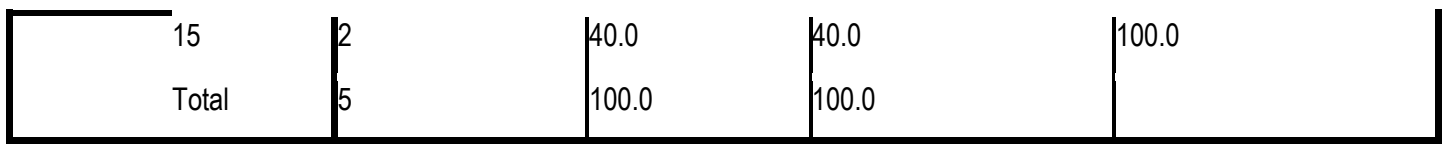

Tab.44 test statistics ${ }^{1}$

Carefull selection of authentic materials

\begin{tabular}{|ll|l|l|l|l|}
\hline & & Frequency & Percent & Valid Percent & Cumulative Percent \\
\hline \multirow{4}{*}{ Valid } & Phd & 1 & 20.0 & 33.3 & 33.3 \\
& Msc & 1 & 20.0 & 33.3 & 66.7 \\
& Not declared & 1 & 20.0 & 33.3 & 100.0 \\
Missing & Total & 3 & 60.0 & 100.0 & \\
Total & & 2 & 40.0 & & \\
\hline
\end{tabular}

Tab.45. test statistics.

The regression model can be used to study the relation between two or more variables and is called Linear model.

R2-is the norm of variances in relation to the total variance and interpreted as the ratio of the observed variance of $Y$ 's to explained by $X$.

\begin{tabular}{|l|l|}
\hline Regression Statistics & \\
\hline Multiple R & 0.273969 \\
\hline R Square & 0.075059 \\
\hline Adjusted R Square & 0.013396 \\
\hline Standard Error & 29.7056 \\
\hline
\end{tabular}

\section{$\mathrm{R} 2=0.075 \times 100=7.5 \%$}

Based on the table it appears that R2 (square), explains $7.5 \%$ of evaluated Variables in our model.

All the academic units of the University of Prishtina organize English language courses, but not all of them offer ESP courses. According to analysis of the data collected at the University of Prishtina, the hypothesis given at the beginning of this research could successfully prove to be true. The age of the teaching staff prevents the use of technology thus, students being not provided with the methods and techniques necessary for the proper conduct of teaching process. Another issue based on the research findings is the literature/ text books in use which do not fulfill students' needs for a professional communication. This irritates students, as they need to look for alternative courses outside the university, which are ESL courses rather than ESP courses. Without being able to use ESP students will not be able to conduct any research in their study field, update their knowledge, participate in different exchange students' programs nor continue their master studies in European universities. They can neither enroll online studies nor compete in the job market. Without mastery of ESP no student can be successful in their future career.

\footnotetext{
${ }^{1}$ This paper is a summer of the author's PhD thesis
} 
Large number of students in teaching rooms equipped with no voice equipment makes the process of teaching and learning difficult. It should be added that especially in the academic units with only one teaching staff, it is really hard to organize classes and divide students into groups as English is taught in the first and second year of studies. The difficulties that teachers of a large class at the UP face are almost the same with those around the world. But circumstances and education culture introduce different situation in our case. First of all when the teacher is responsible for hundreds of students, he/she meets them only once a week, learning names is extremely difficult. The question may arise; what is the role of the students' names? It is really important in case of grading students, because teachers might have it easier when knowing by names which student has been active during the class, which one has paid more attention to the lecture, or which students reached better results in mid-term tests, etc. Large number of students causes noise and misbehavior, assessment and feedback and personal communication consequences. Apart from disadvantages there is still an "advantage" of a large class of students in terms of exam time. Students are aware that they cannot rely only on the teacher for unclear issues during the exam so; they interrupt by asking one another for help, sharing notes and ideas by using cooperative approach. Someone sends answers from outside on phone messages and many other different forms of copies unpredictable by the teacher and if there is not an extra teacher or assistant to help monitor the class, the exam process is really difficult, therefore unfair and dissatisfying results. ${ }^{1}$

The workload can also be considered as a problem in the ESP teaching/learning process, especially in applying modern techniques and teaching methods. Teaching staff, being overloaded, have no time for seminar presentations and as a result some of them are late with the intermediary tests or they do not organize tests at all. This problem considered serious for UP is not a problem of private colleges, as the number of students is much smaller in private institutions of education. Implementation of online services in the University of Prishtina as in private colleges undoubtedly is considered as a great help for the students in getting informed from home about the exam dates and exam results, announcements about possible exam date changes, or for having online consultations with the teaching staff would be a great help. This would facilitate students' contact with their professors/assistants.

One issue raised by students was the matter of not having possibility to complain about their disagreements for assessments. Students need to have a complaints box, because not all students dare to complain orally about the irregularities in the teaching process so, by having an opportunity to submit their anonymous complaints in written form students would feel much relaxed and would not hesitate to do it. However, there are cases of anonymous complaints but not taken into consideration, justifying that there should be a name written on the paper submitted. Existence of a complaint box would be a great help to the teaching/learning process itself. As mentioned in the research, students fill in the evaluation form for each teaching staff and express their complaints towards a certain teacher, it is not considered as a fair one. There is an impression created that if a teacher does not give good grades no matter how hard he/she works or how committed he/she is students are not honest and correct in evaluation. On the other hand, if the teacher is "generous" in grades then he/she will have the best evaluation grade by the students.

\subsubsection{The impact of course status in proper course delivery}

English language, not being a compulsory course taught in every semester, makes students consider that it is not important and consequently is not chosen by them. But, knowing the importance of the English language especially in the job market, it would be necessary for students to have the English course as an obligatory course in all three years of study. This would enable students to apply for studies in European and American universities as full-time students or as exchange students. Reforms at the University require a literature which can be found only in internet or in books written in English language so it is difficult for a student who does not understand ESP to study that literature or use Internet sources. Rare are students who try hard to learn ESP on internet as it required more time than attending a private course or university course.

Apart from having English courses as mandatory courses, it would be much better if these courses would be offered in the third year, too. The question arises: Can students learn ESP only in one or two years of study and only in one semester per year? All prestigious Universities of Europe organize ESP courses in every year of study and in every semester, too. English is not a course that can be learnt in a month or two. It is a course that needs a long time and continuous process.

\footnotetext{
${ }^{1}$ This paper is a summer of the author's PhD thesis
} 
It may be ascertained that the main problem of the University of Prishtina regarding the English courses organized within all seventeen academic units is the shortage of the teaching staff. There are several reasons for this. First of all this problem was caused due to the retirement of a large number of staff from the old generations. Younger generations had no interest to study English or any other field as our country was occupied. Many were more interested to immigrate to Europe. After the war, those who came back were too old to get a place at the University even if they continued their studies. Second source of the shortage of staff is the presence of large number of international organizations after the war. Many English teachers from the University of Prishtina and pre-university education were hired by those organizations being motivated by high salaries, having no interest at all to continue their master or doctoral studies. Even now many teachers of English are more interested to get employed in private universities having possibilities to work in two or more faculties and earn more money. So, only those who are interested to get promoted in the academic hierarchy decide to get a job at the University of Prishtina due to the current regulations according to which private universities cannot provide such an opportunit

\section{Conclusion}

Therefore based on the analysis it can be concluded that:

- The number of English teachers in Kosovo is not sufficient in all levels of education. Primary and secondary schools hire teachers with bachelor degree while university teachers must have at least master degree to get a job as either lecturer or a teaching assistant. The UP has a limited number of English teachers with PhD degree. So, the scientific degree is not the issue that teachers of English courses at the University of Prishtina can proudly discuss about. Still, UP is in a better position than private colleges, as they all hire staff with MSc. or Ma. Degree.

-The age of the teaching staff prevents the use of technology thus students being not provided with the methods and techniques necessary for the proper conduct of teaching process.

- Nowadays almost all universities around the world offer different teacher trainings, conferences and seminars both local and international, aiming the enhancement of the relation between teachers and students that has a great impact on the process of teaching/learning. The University of Prishtina can be one of the participants in such trainings. The proper use of information technology, the possibility of having access to hundreds of internet web pages which provide teaching material both primary and secondary, information on teaching methods, communication etc., access to electronic libraries all over the world etc., are in favor of the teaching/learning process.

- Unfortunately not all academic units of the University of Prishtina neither private colleges offer proper ESP courses. They all offer English language courses, so the literature that they use do not fulfill students' needs for a professional communication. This irritates students as they need to look for alternative courses outside the faculty. Since, not being able to use ESP, students will neither be able to participate in the exchange student programs nor continue their master studies at European universities, have online studies, or compete in the job market.

-Teachers' being overloaded, especially in those academic units with only one teaching staff, find it really hard to organize classes and divide students into groups (they manage it, anyway), as English is taught in the first and second year of studies. Usually the first year (English I) which is obligatory/compulsory course is more difficult while second year (English II), which in some units is taught in the second semester of the first year, being an elective course is much easier having less number of groups with less number of students. So, the workload of teachers can also be considered as a barrier in the ESP teaching/learning process.

-Having English course as elective course makes students consider English less important course and they do not feel strongly obliged to attend it.

Comparative analysis between the University of Prishtina and private colleges shows that in some points private colleges stand in a better position in a sense of respecting rules of holding regular lectures, beginning and ending on time but in a sense of teaching and literature use the University of Prishtina is much better. This might be because of the students' language knowledge which is much lower in private colleges. As for the course status and calculation of ECTS credits there is the same situation in both parties. The calculation of ECTS credits seems to be a problem not only for the English Language courses but for the others too. 


\subsection{Recommendations}

Based on our research findings, it is clear that both teaching staff and students face different barriers and difficulties during the process of teaching and studying ESP. Based on all the answers given by both groups of research population it comes out that there is plenty to be done in order to improve the process of teaching/learning ESP courses at the University of Prishtina. Judging from all what is mentioned above, the following recommendations might be given:

-. Organize on-going trainings for teaching staff

- Establish language laboratories

-Employ more staff, if possible qualified staff in order to have fewer groups with lower number of students in one group for each professor/assistant.

- Introduce English courses as obligatory courses.

- Offer English courses in the third year.

-All academic units be provided with the specific literature relevant to the study field.

Based on all what was said above it can be concluded that process of teaching English for Specific Purposes at the University of Prishtina, as well as at the private university colleges in Kosovo generally leaves a lot to be desired. It is not only the teachers-students relationship to enhance and develop this process, but increased support from the university management would be the greatest incentive. When saying support, it is meant improve working conditions such as the ones mentioned above; more equipped and larger teaching rooms hire additional staff etc. Furthermore, as all employees need to be motivated by different ways such as: money, extra days off, pay raise and so on, it seems that having more control over job and study responsibility as well as being threatened with job / study security would be the best incentive of all. One has to give more in order to get more. Teachers work harder, students more committed towards their studies then the results would be higher. ${ }^{1}$

\section{References}

[1] Alderson. J. and A. H. Urquhart. 1984. Reading in a Foreign Language. London: Longman.

[2] Allison, D. 1996. Pragmatist discourse and English for Academic Purposes. English for Specific Purposes, 15 : 85-104.

[3] Allwright, R. L. 1988. Observation in the Language Classroom. London:Longman.

[4] Amazon.co.uk, Dudley-Evans, Tony (1998). Developments in English for Specific Purposes: A multi-disciplinary approach. Cambridge University Press

[5] Annual Review of Applied Linguistics: An Official Journal of the American Association of Applied Linguistics.

[6] Anthony, L. English for Specific Purposes: What does it mean? Why is it different? Available at http://www.antlab.sci.waseda.ac.jp/abstracts/ESParticle.html

[7] Bell, D. 2002. Help! I've been asked to teach a class on ESP!' in IATEFL Voices, Issue 169, Oct/Nov available at www.usingenglish.com

[8] Blue, G.1993. Language, Learning and Success: Stydying through English development in ELT. London: Macmillan, Modern English teacher and the British Council.

[9] Brennan, J. and Shah, T. 2000. Managing quality in higher education: An international perspective on institutional assessment and change. Buckingham, UK: OECD, SRHE \& Open University Press.

[10] Byram, M. 2000. Rutledge encyclopedia of language teaching and learning

[11] Cambridge University Press. Journal of English for Academic Purposes. Elsevier.

[12] Dickingson, L. 1991. Self-Instruction in Language Learning. Cambridge: Cambridge University Press.

[13] Dill, D. D. "Quality Assurance in Higher Education: Practices and Issues." In P. P. Peterson, E. Baker, and B. McGaw, (eds.), International Encyclopedia of Education, Third Edition, pp. 377-383.

[14] Dudley-Evans, T. 2001. English for Specific Purposes. In the Cambridge guide to TESOL, Cambridge University Press. Available at www.britishcouncil.com

\footnotetext{
${ }^{1}$ This paper is a summer of the author's $\mathrm{PhD}$ thesis
} 
[15] Elsevier.com, English for Specific Purposes An International Research Journal.

[16] Graves, K. 1996. Teachers as course developers. England: Cambridge University Press, 1996.

[17] Harding, K. 2007. English for Specific Purposes, OxfordUniversity Press

[18] Herbert, A.J 1965. The Structure of Technical English. London:Longman.

[19] Higgins, J.J.1966. Hard facts (notes on teaching English to science students). English Language Teaching, 21:55-60.

[20] Holliday, A. 1995.Assesing Language Needs within an Institutional context: an ethnographic approach. English for Specific Purposes. Lancaster University.

[21] Hutchinson, Tom \& Alan Waters. 1987. English for specific purposes: A learning-centered approach. Cambridge: Cambridge University Press.

[22] Journal: English for Specific Purposes: An International Journal. Elsevier.

[23] Krause, C. A. 1916, the Direct Method in Modern Languages, New York.

[24] Munby, J. 1978. Communicative Syllabus Design. Cambridge; Cambridge University Press.

[25] Pratt, D. and Associates, S. Brookfield. 2002. Five perspectives on teaching in adult and higher education, Krieger Publishing Company, USA

[26] Richards, J. \& Lockhart. "Reflective Teaching in SL Classroom", CUP,1995.

[27] Swan, M. 1997. Practical English Usage, Oxford University Press, UK

[28] Tafani, V. 2003. Language Teaching and Learning Methodology. Tiranë. 